\title{
Inhibitory Effect of Lactobacillus plantarum FL75 and Leuconostoc mesenteroides FL14 against Foodborne Pathogens in Artificially Contaminated Fermented Tomato Juices
}

\author{
Aïssé Bah, ${ }^{1}$ Helena Albano $\mathbb{D}^{1},{ }^{2}$ Joana Bastos Barbosa $\mathbb{D}^{\mathbb{D}},{ }^{2}$ Imene Fhoula ${ }^{\mathbb{D}},{ }^{1}$ Yosra Gharbi, \\ Afef Najjari, ${ }^{1}$ Abdellatif Boudabous, ${ }^{1}$ Paula Teixeira $\mathbb{D}^{\mathbb{D}},{ }^{2}$ and Hadda-Imene Ouzari ${ }^{1}{ }^{1}$ \\ ${ }^{1}$ Laboratoire de Microorganismes et Biomolécules Actives (LR03ES03), Faculté des Sciences de Tunis, \\ Université Tunis El Manar, Campus Universitaire, 2092, Tunis, Tunisia \\ ${ }^{2}$ Universidade Católica Portuguesa, CBQF-Centro de Biotecnologia e Química Fina-Laboratório Associado, \\ Escola Superior de Biotecnologia, Rua Arquiteto Lobão Vital 172, 4200-374 Porto, Portugal
}

Correspondence should be addressed to Hadda-Imene Ouzari; ouzari.imene@gmail.com

Received 3 August 2018; Accepted 10 January 2019; Published 26 February 2019

Guest Editor: Marta Laranjo

Copyright (C) 2019 Aïssé Bah et al. This is an open access article distributed under the Creative Commons Attribution License, which permits unrestricted use, distribution, and reproduction in any medium, provided the original work is properly cited.

\begin{abstract}
Tomatoes and tomato based-foods contain beneficial microorganisms and various organic acids that have important nutritional values for human. The objective of this study was to access the physiochemical properties of fermented tomatoes juices and to evaluate the competitiveness of lactic acid bacteria (LAB) against Listeria monocytogenes, Listeria innocua, and Salmonella spp., in artificially contaminated tomato juice. Microbial counting (LAB, fungi Salmonella spp., and Listeria spp.) was performed after fermentation and weekly during storage. Different organic acids (Lactic, succinic, and acetic) and ethanol were also monitored using HPLC method. Color parameters were also determined. The results showed an increase of lactic and acetic acid content, during fermentation and storage of juices inoculated with Lactobacillus plantarum and Leuconostoc mesenteroides at $25^{\circ} \mathrm{C}$. Besides, citric acid and ethanol revealed higher content at the end of storage compared to that registered at $4^{\circ} \mathrm{C}$. The $\mathrm{pH}$ from tomatoes juices decreased from an initial value of 4.5 to below 3.2. Alongside, foodborne pathogen population was significantly suppressed in tomatoes juices when the samples were coinoculated with LAB strains. Moreover, the inhibition of Salmonella species was faster compared to that of Listeria. After four weeks of storage at $4^{\circ} \mathrm{C}, \mathrm{Lb}$. plantarum and $L c$. mesenteroides showed high survival rate, while pathogenic bacteria, yeasts, and molds cell numbers decreased drastically in all the contaminated vials. This work highlights the efficiency of $L b$. plantarum and $L c$. mesenteroides as potential starters for developing nutritious and safe fermented tomato juice products.
\end{abstract}

\section{Introduction}

Tomatoes are one of the major vegetables widely used throughout the world, either in fresh or in processed form, including canned, sun-dried tomatoes, juices, ketchup, mashed tomatoes, sauces, and soups [1]. Tomatoes juices are well recognized by their important nutritional values for human (low cholesterol, fiber and proteins, vitamins as well as $\beta$-carotene, potassium and lycopene, and high content of antioxidants) [2]. Fresh tomatoes, as well as grapes, lettuce, peaches, peppers, spinach, sprouts, are naturally colonized by large microbial populations. Pathogens (e.g., L. monocytogenes, E. coli, and Salmonella spp.) can be part of these populations and may cause food poisoning when eaten as raw product [3]. However, the matrices of fresh tomato contain autochthonous beneficial microbes (e.g., Lb. plantarum, Lc. mesenteroides) which may compete with pathogens and ensure extended shelf life $[4,5]$ Lactobacillus plantarum as well as other LAB were widely used in biopreservation of different food matrices [6]. Sugar content in juice is favorable for microbe proliferation and common foodborne pathogens, which may affect the quality of juice [7]. Fermentation by using LAB as starter carries out acidification, [8], which leads to the decrease of $\mathrm{pH}$ 
and production of lactic acid [9]. Besides, it improves the nutritional, rheological, and sensory properties of fruits [10]. Organic acid (lactic and acetic acid) produced may have an antimicrobial effect, which will therefore depend upon its $\mathrm{pK}$ value (dissociation constant) and the $\mathrm{pH}$ of the external medium [11]. The low $\mathrm{pH}$ of most fruits and vegetables reduces spoilage microbiota, besides, it favors the growth of LAB and fungi [12]. Microorganisms used as probiotics during fermentation of fruits and vegetables are recognized for their nutritional profile and for their health benefit [13]. However, heat treatment process $\left(70^{\circ} \mathrm{C}, 10 \mathrm{~min}\right)$ destroys bacteria and inactivates enzymes [14]. Lactic acid bacteria affected the organic acid production during fermentation, from the metabolism of sugars [15]. Most strains of Lactobacillus plantarum have activity against fungal and spoilage microorganisms, in order to prevent adhesion, establishment, and invasion of enteropathogens such as Salmonella and Listeria [16]. The Food and Agriculture Organization (FAO) of the United Nations and the World Health Organization (WHO) reposed that if the Listeria count does not exceed 100 $\mathrm{CFU} / \mathrm{g}$ at the time of consumption, the food is acceptable [17]. The preservation of vegetables juices by probiotic strains is an important technique for the elaboration of bioproducts and traditional food [18].

The objectives of this work were (i) to evaluate metabolites produced during fermentation and of storage of tomatoes juices, (ii) perform the microbiological analysis and viability of $L A B$ used as starter, and (iii) test the antagonistic activity of LAB against foodborne pathogens in artificially contaminated vials.

\section{Materials and Methods}

2.1. Sampling and Preparation and Fermentation of Tomato Juice. Fresh tomatoes (Lycopersicon esculentum) were purchased from local markets (Portugal) and were taken to the laboratory for experimental analysis.

Tomato fruit was washed with tap water and the seeds as well as skin were removed. Then, the fruits were homogenized by conventional blender (Stomacher Mix ${ }^{\circledR}$ CC Click Clean ${ }^{\circledR}$ ), for $8 \mathrm{~min}$ at room temperature. One hundred milliliters of tomato juices was distributed in $200 \mathrm{ml}$ flask and $1 \mathrm{~g}$ of sucrose was added. The tomato juice was heated in the oven for $5 \mathrm{~min}$ at $70^{\circ} \mathrm{C}$ [4]. The starter strains ( $L b$. plantarum FL75 and Lc. mesenteroides FL14) used were isolated from spontaneous fermentation of tomatoes fruits (of Laboratory Microorganisms and Active Biomolecules "LMBA," Tunisia). The protocol for processing and storage of tomatoes juices is described in Table 1. Lactobacillus plantarum FL75 and Lc. mesenteroides FL14 were mixed and inoculated as starter (4\% $\mathrm{v} / \mathrm{v})$ in tomatoes juices leading to an initial cell number of $10^{11}$ and $10^{9} \mathrm{CFU} / \mathrm{ml}$, respectively.

Also, juice samples were inoculated with pathogens including a mix of $S$. Typhimurium ATCC 14028, S. Enteriditis ATCC 13076, S. Braenderup H9812 [19] or a mix of L. innocua 2030C (culture collection of Escola Superior de Biotecnologia ESB) and L. monocytogenes L7946 [20] at a final concentration of $10^{6} \mathrm{CFU} / \mathrm{ml}$. Control samples were only inoculated with the mix of Listeria and Salmonella species, separately. The procedure was detailed in Table 1. Twelve samples were prepared and stored at $4{ }^{\circ} \mathrm{C}$ and $25^{\circ} \mathrm{C}$ for 30 days as described by [4].

The inoculated juices and control samples were analyzed for growth and viability of strains after fermentation and at 7 , 14,21 , and 28 days of storage. Also, physicochemical analyses and color determination were performed.

2.2. Microbiological Analyses. Viable cells were determined after each week during fermentation of tomatoes juices. One $\mathrm{ml}$ of tomato juice was homogenized in $9 \mathrm{ml}$ of Ringer solution (Lab M). Juice preparation was serially diluted in Ringer solution and counts were done on different agar media: plate count agar (PCA) [21] was used for total counts of aerobic mesophilic $\left(30^{\circ} \mathrm{C}\right.$ for $\left.48 \mathrm{~h}\right)$; Rose Bengal Chloramphenicol (RBC) was used for fungal and yeast $\left(25^{\circ} \mathrm{C}\right.$ for 5 days), Modified Semisolid Rappaport-Vassiliadis agar (MRSV) was used for Salmonella spp. and Oxford agar for Listeria spp. $\left(37^{\circ} \mathrm{C}\right.$ for $\left.48 \mathrm{~h}\right)$ according to Stratakos et al. [22] and De ManRogosa-Sharpe agar (MRS) for lactic acid bacteria $\left(30^{\circ} \mathrm{C}\right.$ for $48 \mathrm{~h}-72 \mathrm{~h})$.

\subsection{Physicochemical Analyses}

2.3.1. Determination of $p H$, Carbohydrates, Organic Acids, Ascorbic Acid, Succinic Acid, and Ethanol. The level of $\mathrm{pH}$ was determined during each week of fermentation by using a Crison Micro pH 2002 pH-meter (Crison, Barcelona, Spain), equipped with an In Lab 427 puncture electrode (Mettler Toledo, Columbus, OH, USA).

After centrifugation of tomatoes juices $(8877 \times \mathrm{g}, 10 \mathrm{~min}$, $4^{\circ} \mathrm{C}$; Rotina 35R, Hettich, Germany), $2 \mathrm{ml}$ of the obtained supernatants was filtered through a $0.20 \mu \mathrm{m}$ disposable syringe filter. The filtrate was analyzed by high-performance liquid chromatography (HPLC) equipped with a UV detector operated at $210 \mathrm{~nm}$, using a Shim-pack SCR-101H column $(7.9 \mathrm{~mm} \times 30 \mathrm{~cm})$. The concentrations of different compounds such as fructose and glucose, nonvolatile acids (citric, lactic, and ascorbic acids), acetic acid, and ethanol were determined. The analysis was performed at $30^{\circ} \mathrm{C}$ by using $100 \mathrm{mM}$ perchloric acid as the eluent at a flow rate of $0.6 \mathrm{ml} / \mathrm{min}$ with a sample volume of $0.02 \mathrm{ml}$. Lactic and citric acids were identified by a comparison of the retention time of an authentic standard corresponding to each acid. The concentration was determined using a calibration curve obtained by different standard concentrations of each sample in the same conditions used for sample analysis. The assay was performed in duplicate according to Ferrari et al. and Barbosa et al. [23, 24].

2.3.2. Color Measurements. The color measurements were performed to each sample each week during fermentation of tomatoes juices. The measurements were performed in the CIE (Commission Internationale de L'Eclairage) Lab color scale, using a Konica Minolta CR-300 Chroma Meter (Konica Minolta, Tokyo, Japan) colorimeter. The analysis consists in an evaluation of the color parameters $\mathrm{L} *, \mathrm{a} *$, and $\mathrm{b} * \mathrm{~L} *$ value 
TABLE 1: Different treatment of tomatoes juices.

\begin{tabular}{|c|c|}
\hline Samples & Code \\
\hline 1. Non inoculated juice & Control \\
\hline 2. Juices inoculated with $L b$. plantarum & Lb. plantarum \\
\hline 3. Juices inoculated with $L c$. Mesenteroides & Lc. mesenteroides \\
\hline 4. Juices inoculated with $L b$. plantarum and Lc. mesenteroides & Lb. plantarum + Lc. mesenteroides \\
\hline 5. Juices inoculated with Mix of Salmonella species and Lb. plantarum & Salmonella + Lb. plantarum \\
\hline 6. Juices inoculated with Salmonella species and Lc. mesenteroides & Salmonella + Lc. mesenteroides \\
\hline 7. Juices inoculated with Salmonella species, Lb. plantarum and Lc. Mesenteroides & Salmonella + Lb. plantarum + Lc. mesenteroides \\
\hline 8. Juices inoculated with Mix of Salmonella species & Salmonella \\
\hline 9. Juices inoculated with Mix of Listeria species & Listeria \\
\hline 10. Juices inoculated with Listeria species and $L b$. plantarum & Listeria + Lb. plantarum \\
\hline 11. Juices inoculated with Listeria species and Le. mesenteroides & Listeria+ Lc. mesenteroides \\
\hline 12. Juices inoculated with Listeria species, $L b$. plantarum and $L c$. mesenteroides & Listeria + Lb. plantarum $+L c$. mesenteroides \\
\hline
\end{tabular}

measures the lightness of the sample, ranging from 0 (black) to 100 (white), a* varies between red $(+a *)$ and green $(-a *)$, and $\mathrm{b} *$ varies between yellow $(+\mathrm{b} *)$ and blue $(-\mathrm{b} *)$ color space. Three color measurements were performed for each sample. The chroma value was calculated, which indicates the color intensity and saturation (Chroma $=(a * 2+b * 2) \wedge 1 / 2)$ and the hue angle, which measures the highlights, midtones, and shadows (Hue angle $=\tan -1(\mathrm{~b} * / \mathrm{a} *)$ [25].

\section{Results and Discussion}

3.1. Microbiological Analysis. Cell counts of LAB ranged between $10^{8}$ and $10^{11} \mathrm{CFU} / \mathrm{ml}$ during the fermentation (Figure 1). Moreover, LAB counts of tomatoes juices inoculated with strains of $L c$. mesenteroides and $L b$. plantarum remain high during the first weeks until 21 days of storage. The result was similar to that obtained by Mousavi et al. [26]. Cell viability obtained at the beginning of fermentation in the tomatoes juice inoculated with LAB was higher compared to the control sample.

Fast growth of lactic acid bacteria in tomatoes juices showed to be advantageous, because there was production of organic acid, resulting in rapid fermentation periods. As indicated by Pereira et al. [27], tomato juice inoculated with $L b$. plantarum and $L c$. mesenteroides has showed high production of organic acids compared to the control samples in both conditions. Lactic acid and low $\mathrm{pH}$ in juices influence the viability of LAB at the end of storage in fermented tomato juice samples at 4 and $25^{\circ} \mathrm{C}$. This result confirms the metabolism effect of the $L b$. plantarum and $L c$. mesenteroides used as starter for tomatoes juices acidification. Higher $\mathrm{pH}$ values in the control samples could be due to the occurrence of autochthonous lactobacilli with low acidifying effect power. In addition, high $\mathrm{pH}$ value of the control samples could be due to the superficial development of molds which lead to the loss of acidification and deaminase activities as also reported by Merchesini et al. or Sunesen and Stahnke $[28,29]$. The number of yeasts and molds was increased gradually from day 14 of fermentation for both inoculated and control tomato juices. However, in the juices inoculated with $L b$. plantarum FL75 and Lc. Mesenteroides FL14, the cell density of spoilage yeasts and molds was markedly lower than that found frequently in samples subjected to spontaneous fermentation (control), indicating the antifungal action of LAB used as starter. These findings are similar to other studies conducted either for fermented foods [30] or for food preservation $[31,32]$. Antilisterial activity by LAB ( $L b$. plantarum and Lc. mesenteroides) coinoculated in tomatoes juices was detected by diminishing the growth rate of Listeria at the end of fermentation and its total inhibition after one week of storage conditions (Figure 2). This behavior was also observed when $L b$. plantarum was inoculated alone, with the difference that total inhibition of Listeria was obtained after two weeks of storage at $4^{\circ} \mathrm{C}$. However, when tomatoes juices were inoculated with $L c$. mesenteroides, total inhibition was observed only for storage conditions of $25^{\circ} \mathrm{C}$, after two weeks. Such difference in viability upon storage temperature may be due to the reduced growth rate and secondary metabolites release at $4^{\circ} \mathrm{C}$. Besides, total inhibition of Listeria was not observed for the control samples. It was only reduced to 2.1 $\mathrm{CFU} / \mathrm{ml}$ at $25^{\circ} \mathrm{C}$. The obtained results highlight the importance of use and selection of starters and the effectiveness of Lb. plantarum compared to Lc. mesenteroides in inhibiting Listeria population. As it was previously reported by Alves et al. and Albano et al. [33, 34], antilisterial activity was due to the effect of LAB, which showed high viability rate after fermentation and during storage (Figure 2).

Similarly, monitoring of Salmonella viability in contaminated tomato juice revealed that when LAB count was increased, the cell counts of Salmonella were reduced after storage at 4 and $25^{\circ} \mathrm{C}$ for 28 days. In control samples, Salmonella counts were also decreased progressively during storage at $4^{\circ} \mathrm{C}$ and slightly differ from which observed in samples kept at $25^{\circ} \mathrm{C}$ (Figure 3), suggesting the involvement of various antimicrobial compounds (acetic and lactic acid, hydrogen peroxide $\left(\mathrm{H}_{2} \mathrm{O}_{2}\right)$, and bacteriocin). This result was in accordance with those obtained by Li et al. [35], showing an antagonistic effect by LAB against Salmonella. These findings confirm the observations obtained by Fazeli et al.; Brillet et al.; and Budde et al. [36-38], which suggested that application 


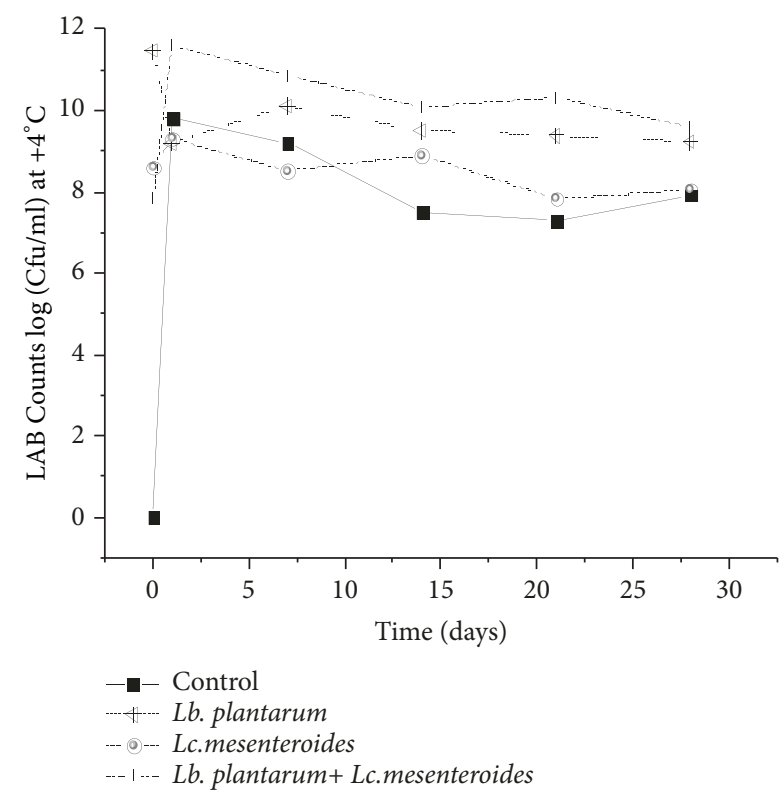

(a)

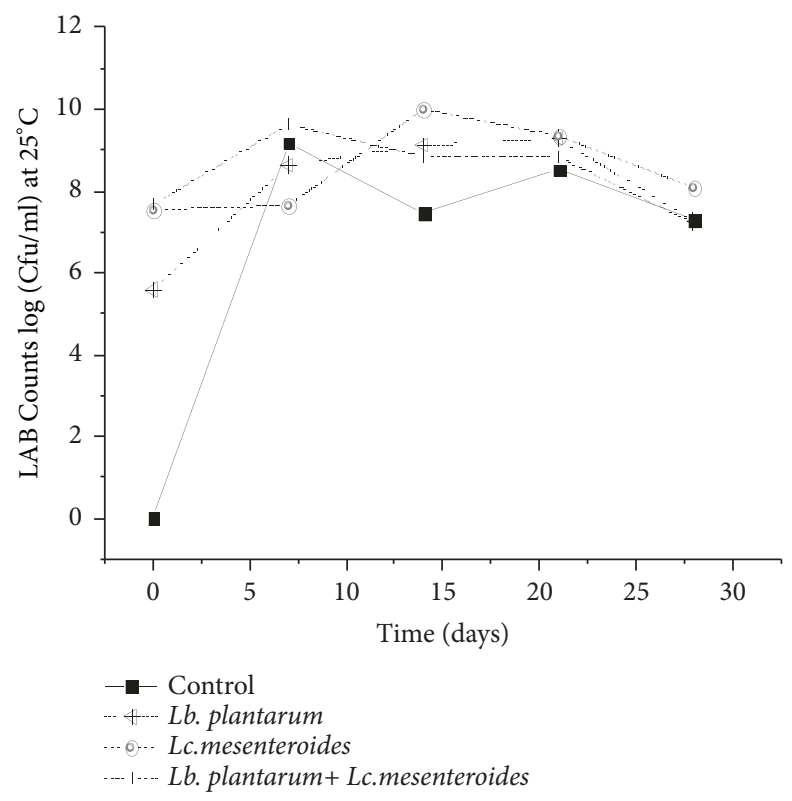

(b)

Figure 1: The growth of LAB in tomatoes juices after $24 \mathrm{~h}$ of fermentation and during storage at $4^{\circ} \mathrm{C}(\mathrm{a})$ and $25^{\circ} \mathrm{C}(\mathrm{b})$.

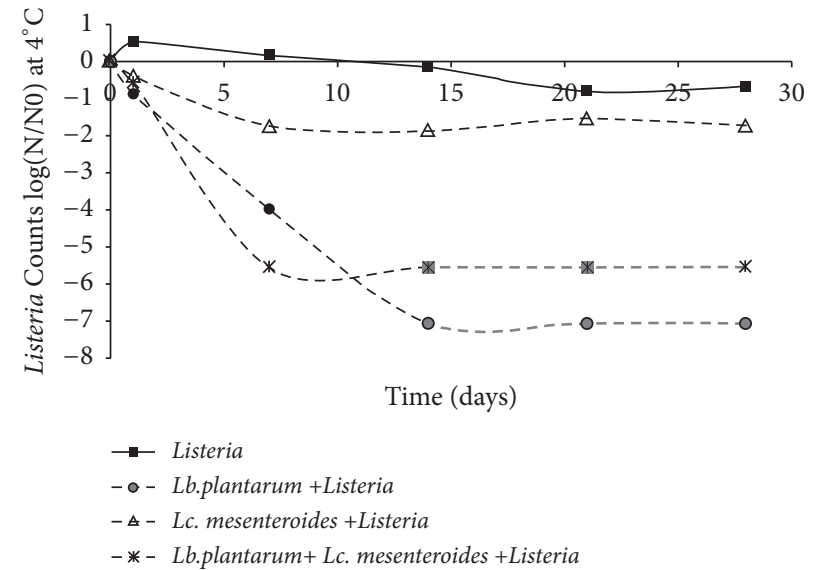

(a)

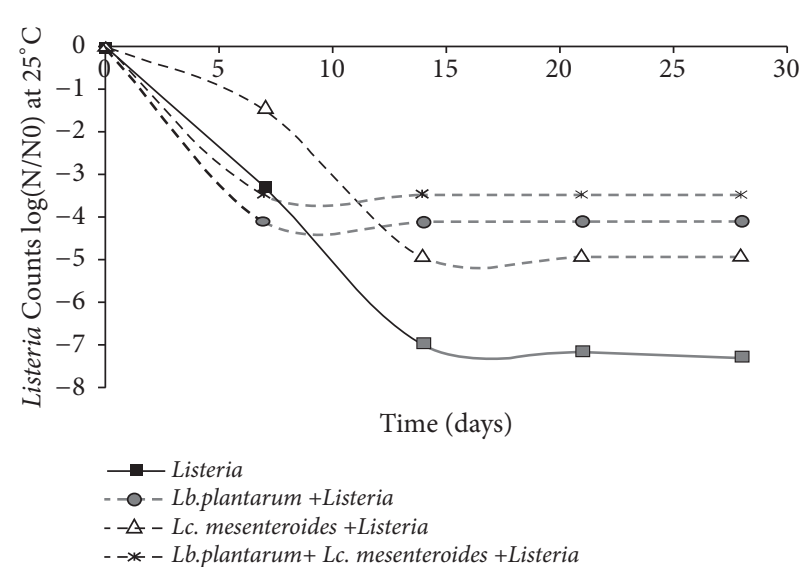

(b)

FIGURE 2: Logarithmic reduction of Listeria species by LAB in tomatoes juices after $24 \mathrm{~h}$ of fermentation and during storage at $4^{\circ} \mathrm{C}$ (a) and $25^{\circ} \mathrm{C}$ (b). The control used corresponds to Listeria(black square with solid line), Lb.plantarum + Listeria(gray circle with dashed line), Lc. mesenteroides + Listeria (empty triangle with dashed line), and Lb.plantarum + Lc. mesenteroides + Listeria(asterisk with dashed line). The gray lines mean that the isolate was reduced to values below the detection limit of the enumeration technique.

of selected LAB as starter cultures allowed fast growth rate in the fermented products at different temperatures. LAB counts increased rapidly at the beginning of fermentation, allowing the $\mathrm{pH}$ decrease, due to the metabolic activity of LAB which inhibit pathogens.

3.2. Physicochemical Analyses. The results showed that the evolution of $\mathrm{pH}$ in tomatoes juices was similar in both storage conditions at $4^{\circ} \mathrm{C}$ and $25^{\circ} \mathrm{C}$ (Figure 4 ). The $\mathrm{pH}$ was decreased progressively from initial value 4.2 to about 3.6, after 7 days and 3.4 after 28 days, while the control sample revealed a slightly higher $\mathrm{pH}$ compared to the inoculated samples. The $\mathrm{pH}$ of tomatoes juices inoculated with $\mathrm{Lb}$. plantarum FL75 varied from 4.2 to 3.38 after 14 days of storage at $4^{\circ} \mathrm{C}$, with a slight increase until 3.55 after 21 days. This finding is in agreement with similar studies reported by Georgieva et al. [39]. High $\mathrm{pH}$ values in the control samples and all samples inoculated after 14 days of storage could be due to the occurrence of molds. Moreover, the coinoculated samples with $L b$. plantarum FL75 and Lc. mesenteroides FL14 showed 


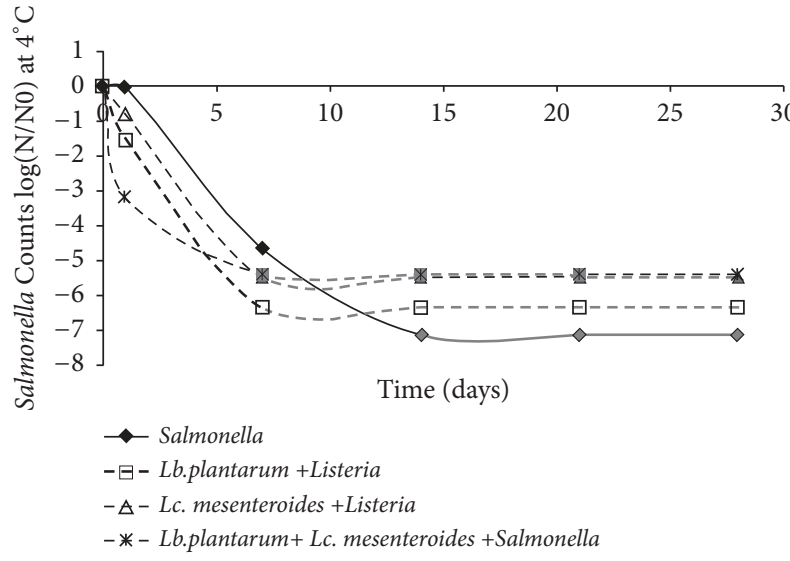

(a)

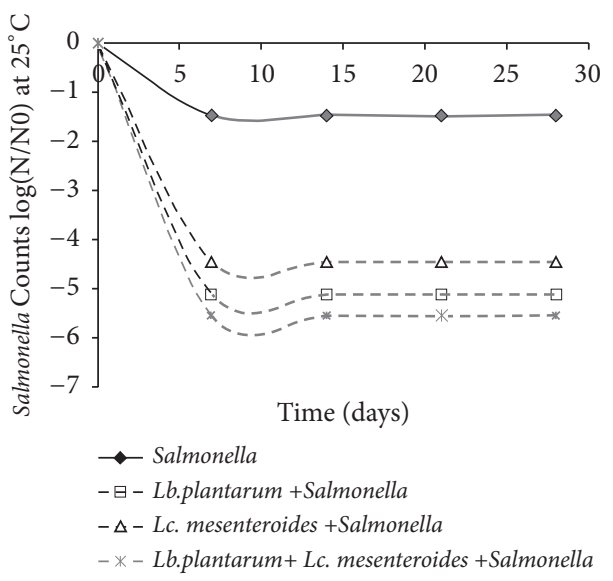

(b)

FIGURE 3: Logarithmic reduction of Salmonella species by LAB in tomatoes juices after $24 \mathrm{~h}$ of fermentation and during storage at $4^{\circ} \mathrm{C}$ (a) and $25^{\circ} \mathrm{C}$ (b). The control used corresponds to Salmonella(black diamond with solid line), Lb.plantarum+ Salmonella(empty square with dashed line), Lc. mesenteroides+ Salmonella(empty triangle with dashed line), and Lb. plantarum + Lc. mesenteroides + Salmonella(asterisk with dashed line). The gray lines mean that the isolate was reduced to values below the detection limit of the enumeration technique.

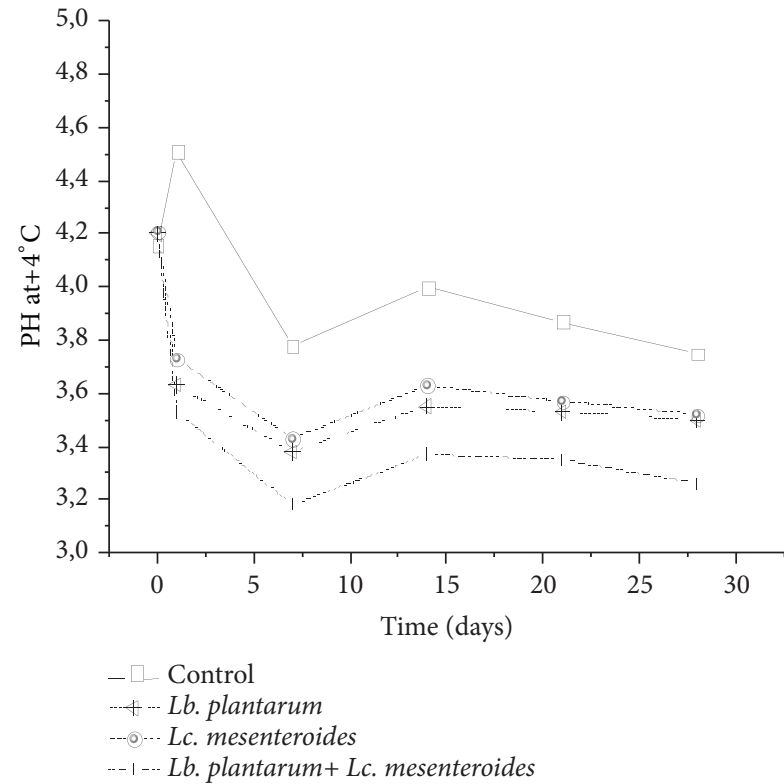

(a)

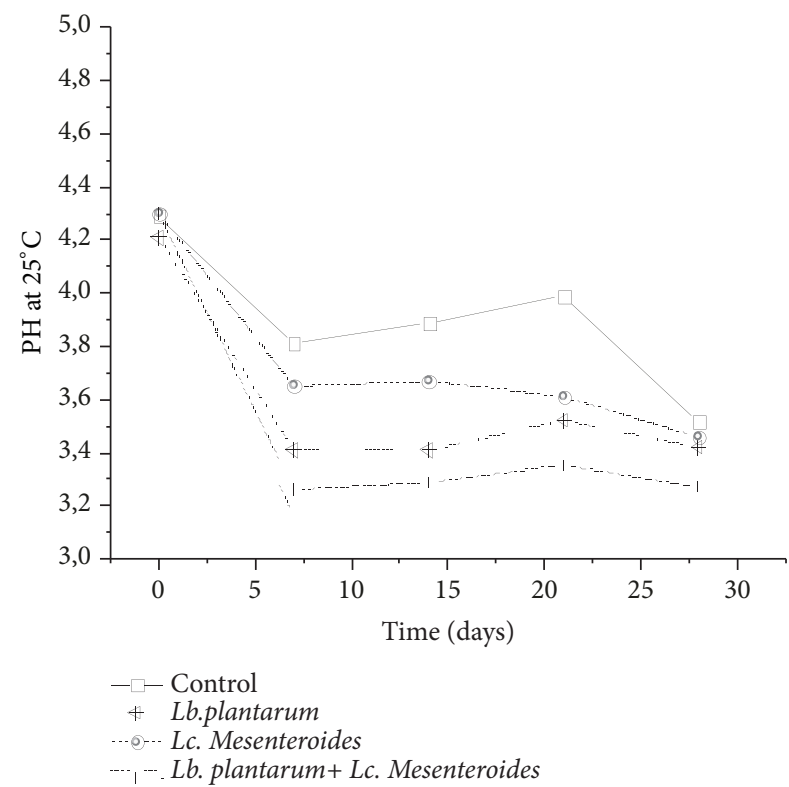

(b)

FIGURE 4: $\mathrm{pH}$ variation monitoring in tomatoes juices after $24 \mathrm{~h}$ of fermentation and during storage at $4^{\circ} \mathrm{C}(\mathrm{a})$ and $25^{\circ} \mathrm{C}(\mathrm{b})$.

a lower $\mathrm{pH}$ in all the analyzed samples. Accumulation of organic acids confirmed the strong acidifying activity of LAB used as starter, which is in concordance with those obtained by Di Cagno et al. [10].

The concentrations of citric acid, L-ascorbic acid, and succinic acid were decreased in all tomatoes juices subjected to spontaneous fermentation and starter-fermented tomatoes juice (Figures 5 and 6). The L-ascorbic acid content diminished from $176 \mathrm{mg} / \mathrm{l}$ to $46.43 \mathrm{mg} / \mathrm{l}$. Besides succinic acid content ranged to $2.7 \mathrm{~g} / \mathrm{l}$ and to $1.12 \mathrm{~g} / \mathrm{l}$ in tomatoes juices inoculated with $L c$. mesenteroides FL14 during storage at $4^{\circ} \mathrm{C}$, which is in concordance with Hernández et al. [40].
The degradation of ascorbic, succinic, and citric acid was greater rapidly during storage at $25^{\circ} \mathrm{C}$ compared to $4{ }^{\circ} \mathrm{C}$ (Figures 5 and 6). This is due to the use of citric, succinic, and ascorbic acid by LAB as energy source during storage.

However, the concentrations of ethanol were increased with a maximum at day 14 in both storage temperatures followed by a slight decrease (Figure 7). The concentrations of ethanol were increased in tomatoes juices inoculated with $L b$. plantarum FL75 and Lc. mesenteroides FL14 at the end during storage of $25^{\circ} \mathrm{C}$, which suggests that the inoculated LAB were totally responsible for ethanol production [41, 42]. Heating of tomatoes juices before starter cultures 


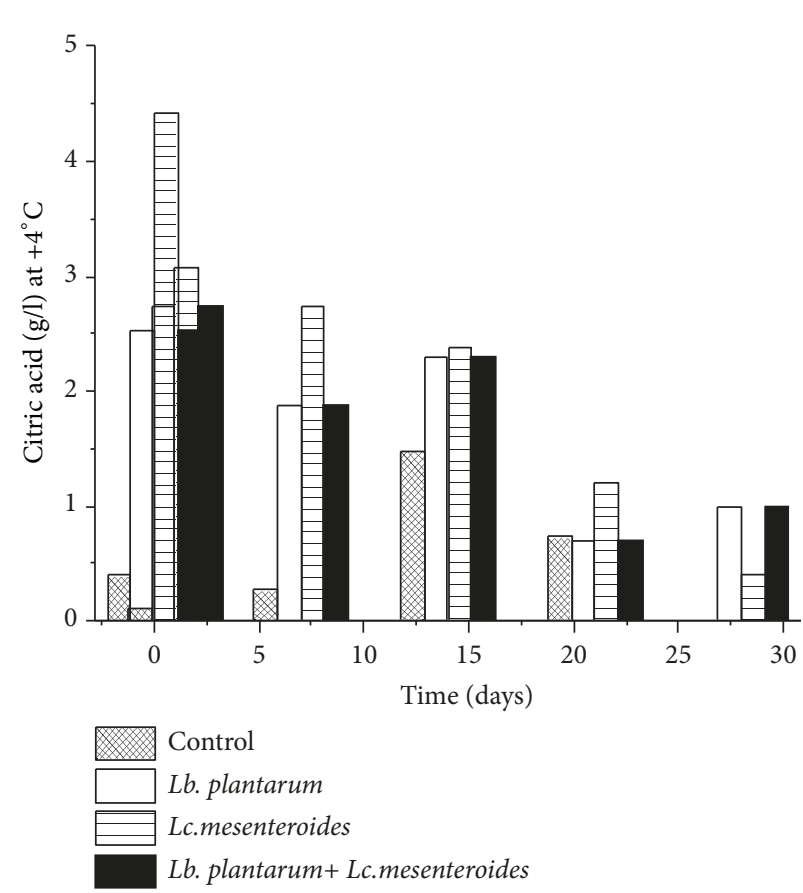

(a)

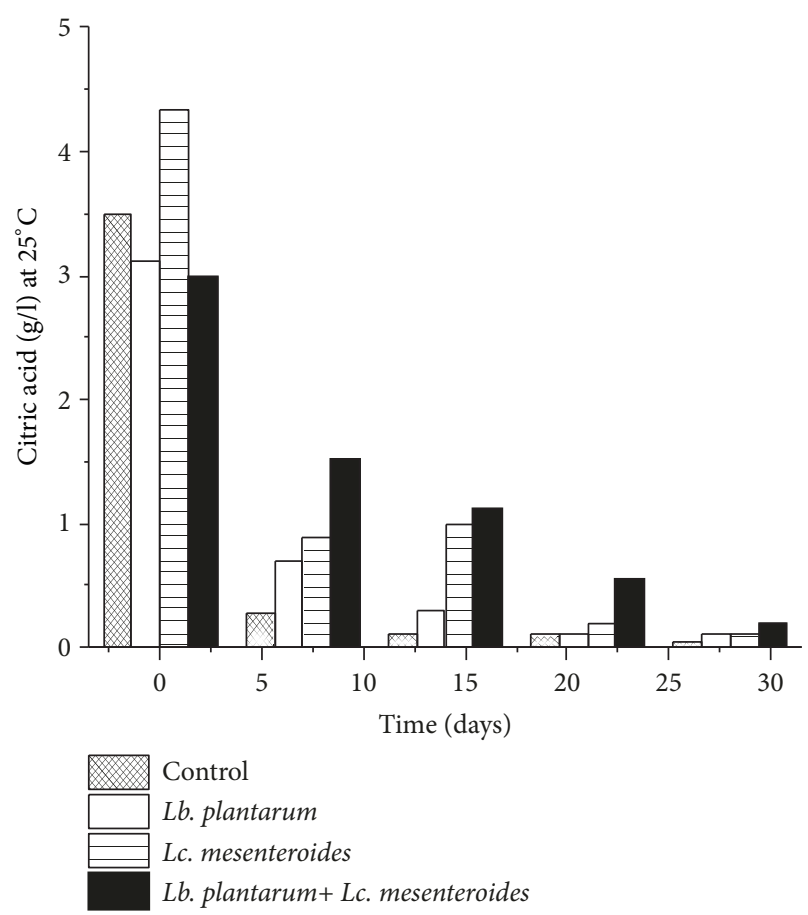

(b)

FIgURE 5: Citric acid quantification in tomatoes juices after $24 \mathrm{~h}$ of fermentation and during storage at $4^{\circ} \mathrm{C}(\mathrm{a})$ and $25^{\circ} \mathrm{C}(\mathrm{b})$.

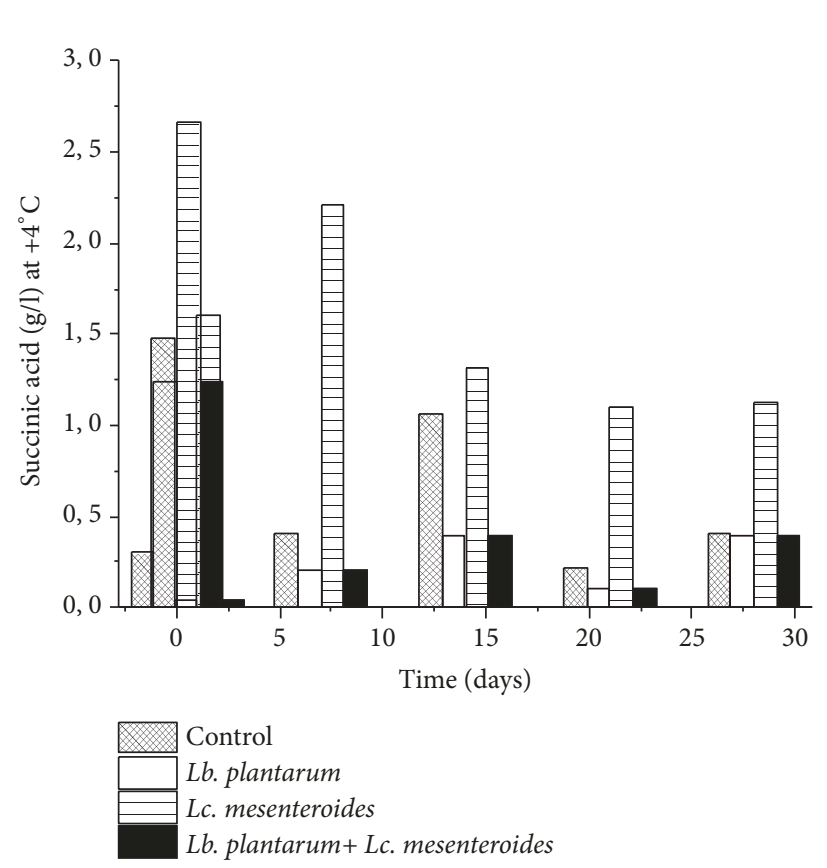

(a)

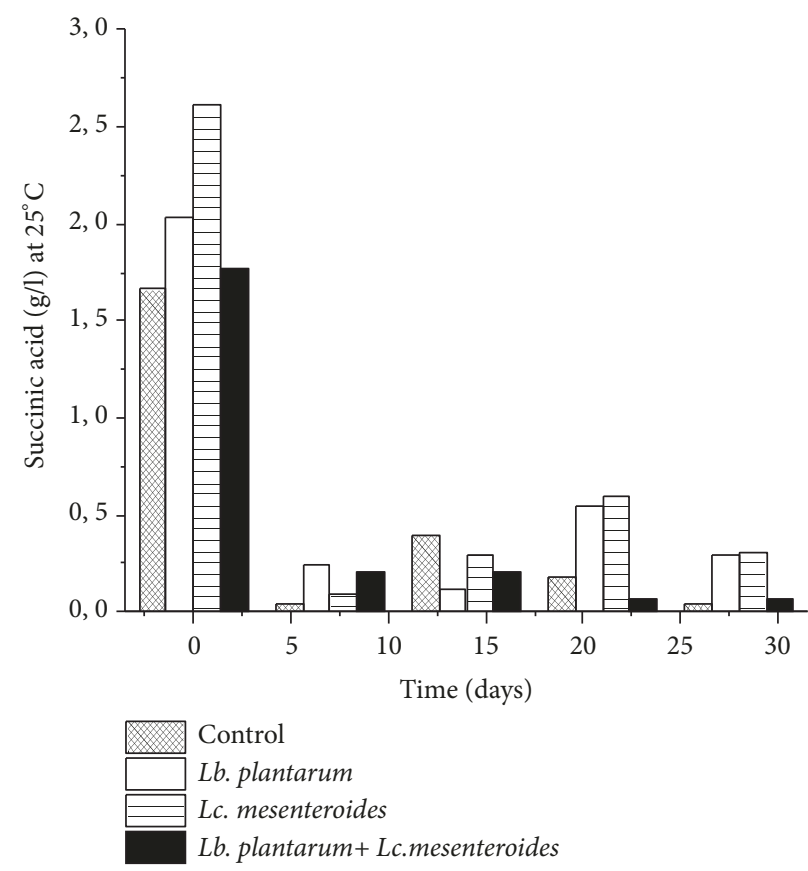

(b)

FIGURE 6: Evolution of Succinic acid amount after $24 \mathrm{~h}$ of fermentation and during storage at $4^{\circ} \mathrm{C}$ (a) and $25^{\circ} \mathrm{C}$ (b).

inoculation decreases the load of foodborne pathogenic bacteria and promotes the growth and proliferation of lactic acid bacteria during fermentation and storage, leading to the production of healthy and nutritional tomatoes juices, which verify the properties probiotic beverages [43]. The growth of LAB depends on the substrate such as glucose (very good carbon and energy source) and even on the fermentation time, which explained the reduction of carbohydrates (glucose and fructose) in tomatoes juices stored at $4^{\circ} \mathrm{C}$ and $25^{\circ} \mathrm{C}$. This result is in agreement with those of Reddy et al. [44], obtained for mango juice fermentation. 


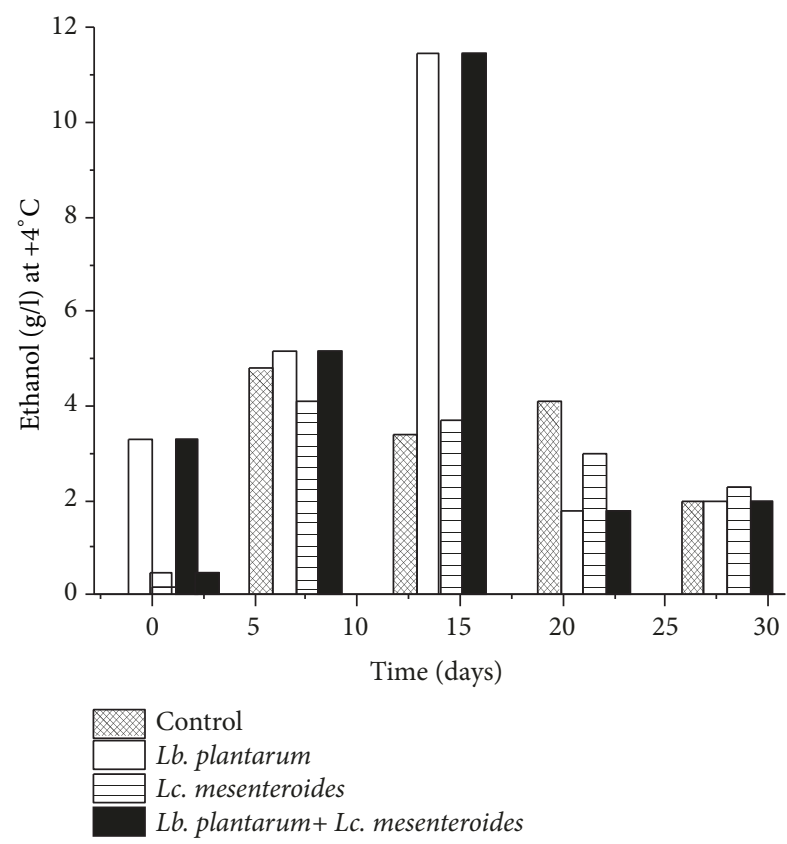

(a)
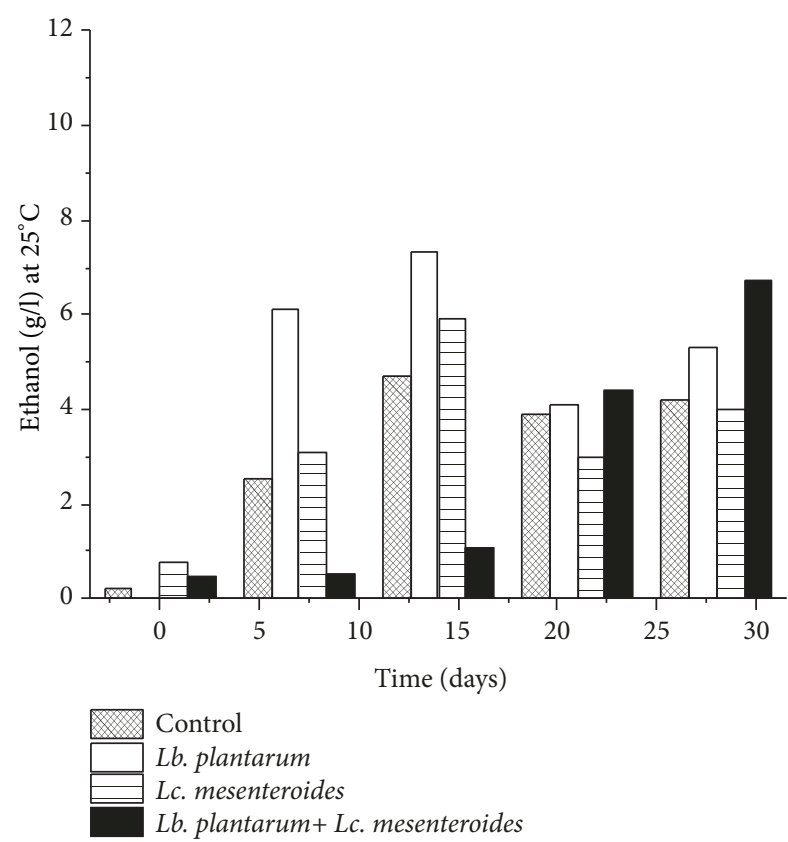

(b)

FIgURE 7: Production of bioethanol in tomatoes juices after $24 \mathrm{~h}$ of fermentation and during storage at $4^{\circ} \mathrm{C}(\mathrm{a})$ and $25^{\circ} \mathrm{C}(\mathrm{b})$.

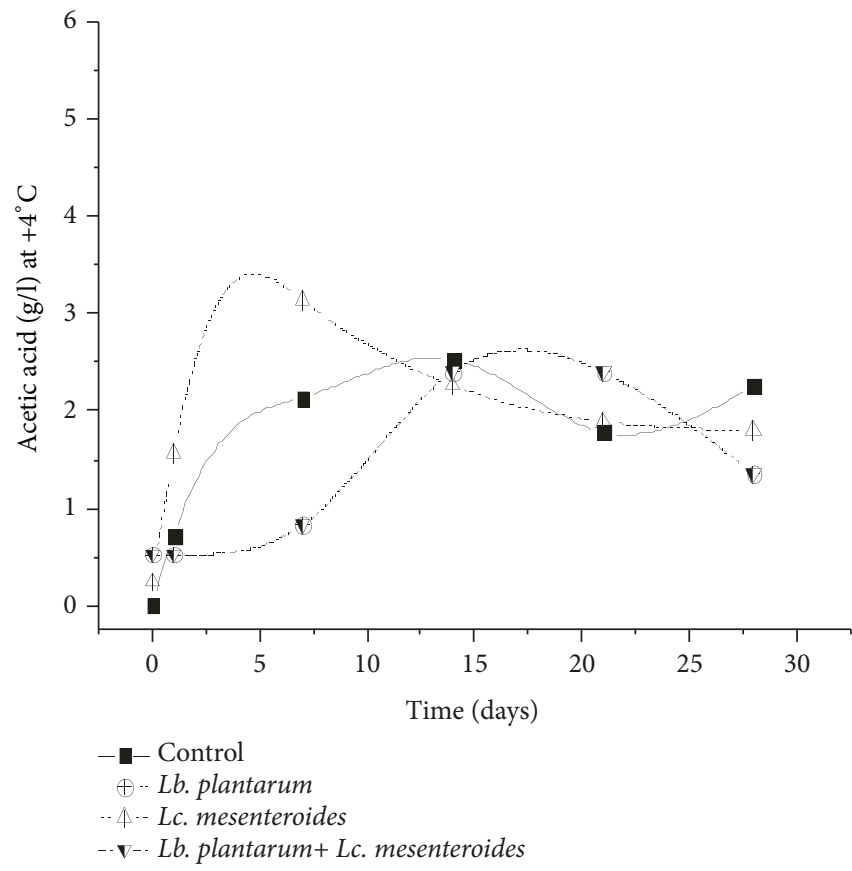

(a)

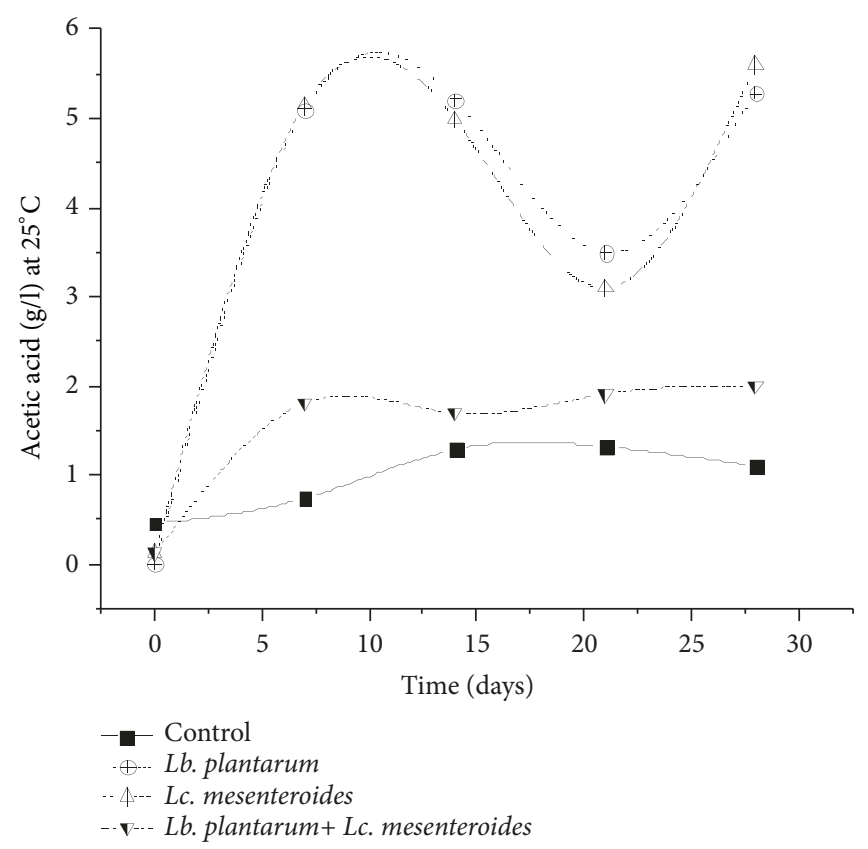

(b)

Figure 8: Acetic acid content in tomatoes juices after $24 \mathrm{~h}$ of fermentation and during storage at $4^{\circ} \mathrm{C}$ (a) and $25^{\circ} \mathrm{C} \mathrm{(b).}$

Besides, organics acids were determined to evaluate their content variation upon LAB starter use in the tomatoes juices and control sample during fermentation and storage. Organic acid such as lactic and acetic acids has shown high amount in tomatoes juices inoculated with LAB starter compared to the control sample (Figure 8), which can affect the flavor of the final product due to the activity of lipases. However, higher content was noticed for samples inoculated with $L b$. plantarum compared to those inoculated with $L c$. mesenteroides (Figure 9). Higher amount of acids was also registered for juice samples inoculated with $\mathrm{LAB}$ and stored at $25^{\circ} \mathrm{C}$ than juices stored at $4^{\circ} \mathrm{C}$. These results are in agreement with 


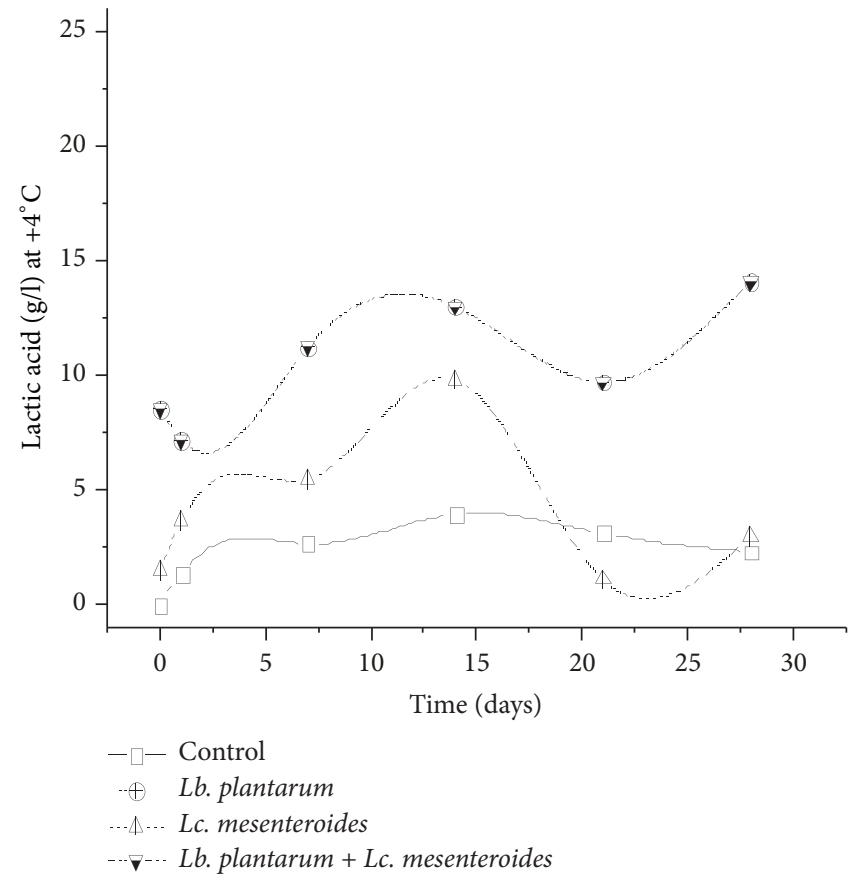

(a)

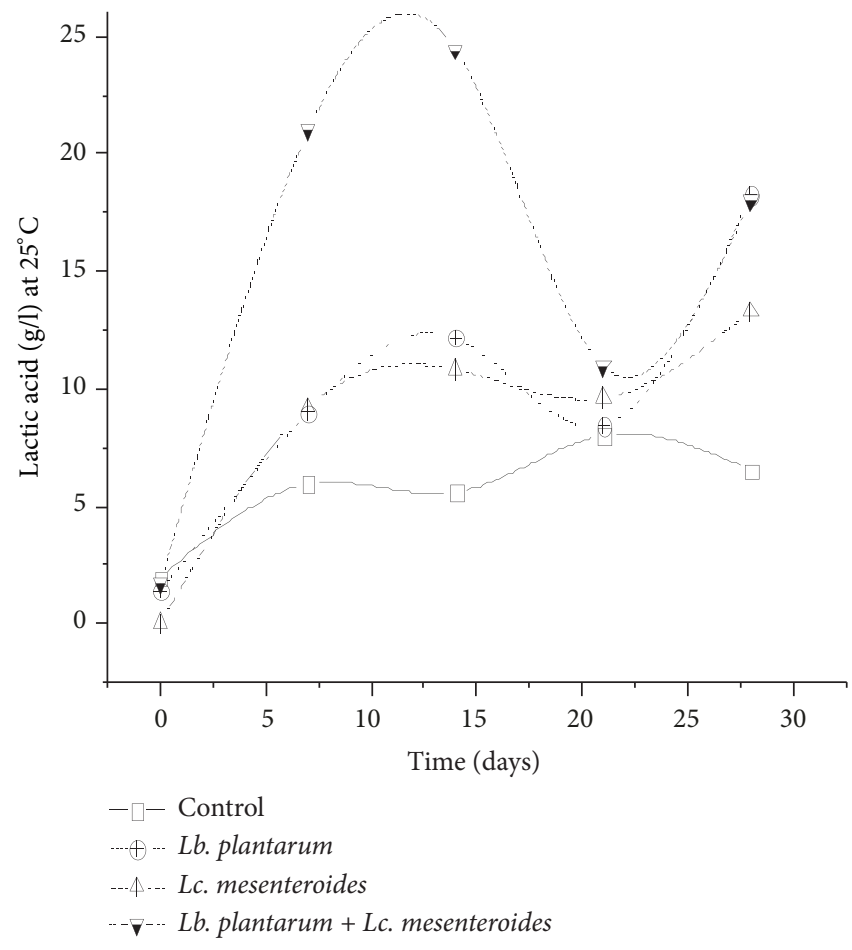

(b)

Figure 9: Concentration of lactic acid in tomatoes juices after $24 \mathrm{~h}$ of fermentation and during storage at $4^{\circ} \mathrm{C}$ (a) and $25^{\circ} \mathrm{C}(\mathrm{b})$.

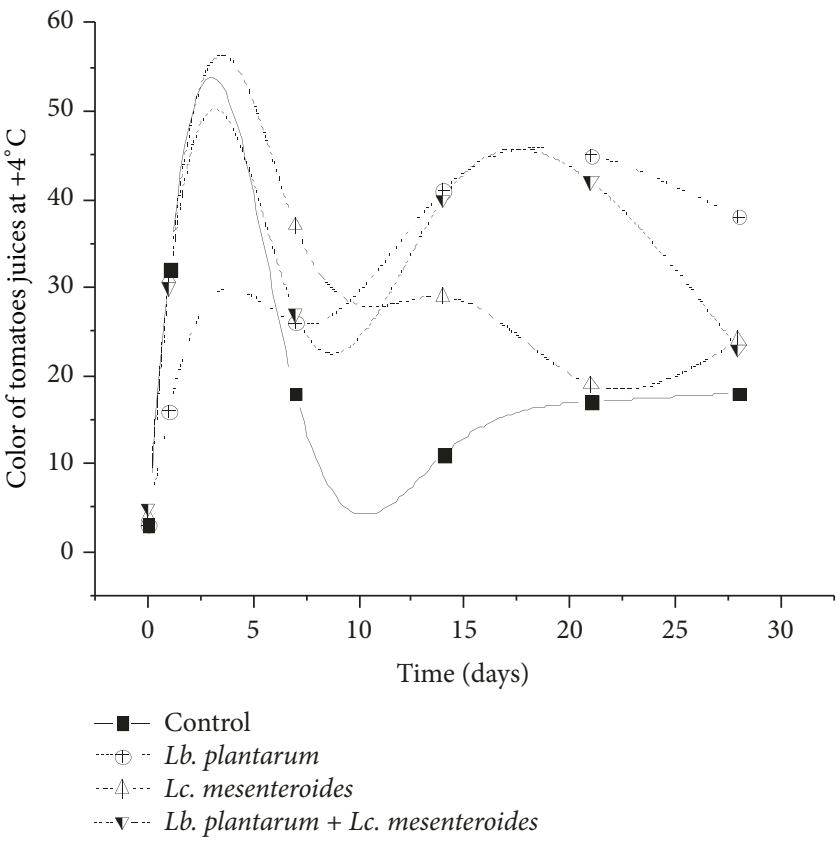

(a)

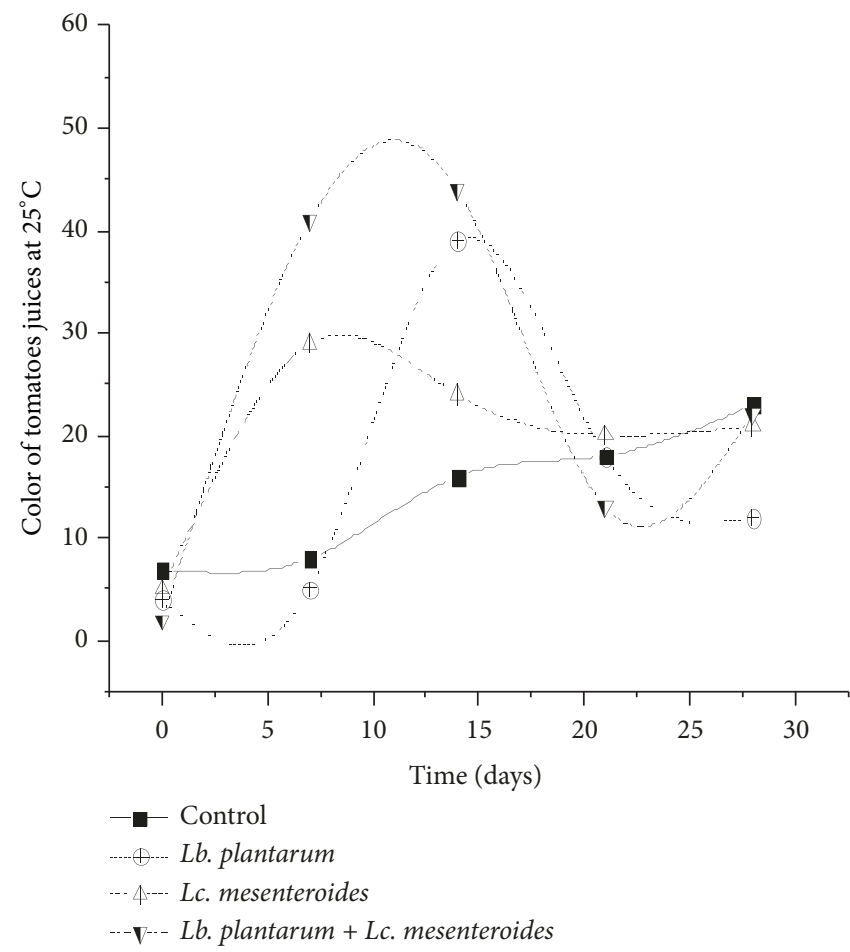

(b)

FIgURE 10: Color component of tomatoes juices. 
Kohajdova et al. and Perez et al. [21, 45], which reported the production of organic acids by $L b$. plantarum in vegetables juices.

Fruit acidity and sweetness are among the major factors determining the quality of tomatoes juices, by decreasing the $\mathrm{pH}$ during fermentation and storage, which correlated with the high quantity of organic acids [46].

As indicated by Essid et al. [30], the acidifying activities of $L b$. plantarum in vivo were demonstrated by inhibition of spoilage microorganism of Listeria and Salmonella in the inoculated tomatoes juices compared to the control samples. The antimicrobial activity is translated by the undissociated form of the acid which can cross the microbial membrane and inhibit pathogenic bacteria such as Salmonella, Listeria, and the spoilage molds. According to the Henderson-Hasselbalch equation [47] the antimicrobial activity is effective when the amounts of acetic acid and lactic acid have reached 0 $22 \mathrm{mg} / \mathrm{g}$ and 1-68 mg/g, respectively. Strong accumulation of lactic and acetic acids in tomatoes juices suggests antimicrobial activity against Salmonella, Listeria, and spoilage molds, in vivo. Moreover, in accordance with Jankuloski et al. [48], pathogenic bacteria and the spoilage molds were decreased after 14 days of storage at $4^{\circ} \mathrm{C}$ and $25^{\circ} \mathrm{C}$, due of the effect of acetic and lactic acids in all tomatoes juices.

Red color of tomatoes juices is related to the concentration of its pigments (carotenoids and lycopen) and is one of the organoleptic properties often evaluated. Ours results indicated intense color development in tomato juices inoculated by LAB compared to the control samples (Figure 10). Moreover, juices samples inoculated only with $L b$. plantarum or the mixed of $L b$. plantarum and Lc. mesenteroides showed higher color intensity than those inoculated only by $L c$. mesenteroides, particularly after ten days of storage. These results are in agreement with those of Gould et al. [49], reporting the variation of color during storage of tomato juice.

\section{Conclusion}

The results of this study highlight the effectiveness of LAB starter in inhibiting foodborne pathogens of Listeria spp. and Salmonella spp. species during fermentation and storage of fermented tomatoes juices. Lb. plantarum associated or not with $L c$. mesenteroides have shown high viability in the tomato matrix and has exhibited high level of organic acids, ethanol, and color development. The selected LAB starter has proven efficiency in the development and biopreservation of dietetical and safe functional food with important shelf life at both room and refrigerated temperatures.

\section{Data Availability}

The data used to support the findings of this study are available from the corresponding author upon request. The nucleotide sequences data used to support the findings of this study are publicly available in the GenBank repository at National Center for Biotechnology Information
NCBI (https://www.ncbi.nlm.nih.gov/genbank/), Lactobacillus plantarum FL75 MH037134; Leuconostoc mesenteroides FL14 MH037132.

\section{Conflicts of Interest}

The authors declare that there are no conflicts of interest regarding the publication of this paper.

\section{Acknowledgments}

The authors thank for the financial support the Tunisian Ministry of Higher Education and Scientific research in the ambit of the laboratory Project LR03ES03. This work was scientifically supported by National Funds from the Fundação para a Ciência e a Tecnologia (FCT) through Project UID/Multi/50016/2013 and through Project "Biological tools for adding and defending value in key agrofood chains (bio - n2 - value)," n NORTE-01-0145-FEDER000030, funded by Fundo Europeu de Desenvolvimento Regional (FEDER), under Programa Operacional Regional do Norte-Norte2020."

\section{Supplementary Materials}

The result of Biolog phenotypic microarray analysis data used to support the findings of this study are included within the supplementary information file. (Supplementary Materials)

\section{References}

[1] H. D. Sesso, J. E. Buring, E. P. Norkus, and J. M. Gaziano, "Plasma lycopene, other carotenoids, and retinol and the risk of cardiovascular disease in women," American Journal of Clinical Nutrition, vol. 79, no. 1, pp. 47-53, 2004.

[2] J. Shi and M. Le Maguer, "Lycopene in tomatoes: chemical and physical properties affected by food processing," Critical Reviews in Food Science and Nutrition, vol. 40, no. 1, pp. 1-42, 2000.

[3] J. W. Leff and N. Fierer, "Bacterial communities associated with the surfaces of fresh fruits and vegetables," PLOS ONE, vol. 8, no. 3, Article ID e59310, pp. 1-9, 2013.

[4] R. Di Cagno, R. F. Surico, A. Paradiso et al., "Effect of autochthonous lactic acid bacteria starters on health-promoting and sensory properties of tomato juices," International Journal of Food Microbiology, vol. 128, no. 3, pp. 473-483, 2009.

[5] K. Pingulkar, A. Kamat, and D. Bongirwar, "Microbiological quality of fresh leafy vegetables, salad components and readyto-eat salads: An evidence of inhibition of Listeria monocytogenes in tomatoes," International Journal of Food Sciences and Nutrition, vol. 52, no. 1, pp. 15-23, 2001.

[6] R. Di Cagno, G. Minervini, E. Sgarbi et al., "Comparison of phenotypic (Biolog System) and genotypic (random amplified polymorphic DNA-polymerase chain reaction, RAPD-PCR, and amplified fragment length polymorphism, AFLP) methods for typing Lactobacillus plantarum isolates from raw vegetables and fruits," International Journal of Food Microbiology, vol. 143, no. 3, pp. 246-253, 2010.

[7] S. Pao, W. W. Widmer, and P. D. Petracek, "Effects of cutting on Juice leakage, microbiological stability and bitter substances of 
peeled citrus," Lebensmittel-Wissenschaft und-Technologie, vol. 30, no. 7, pp. 670-675, 1997.

[8] N. J. Gardner, T. Savard, P. Obermeier, G. Caldwell, and C. P. Champagne, "Selection and characterization of mixed starter cultures for lactic acid fermentation of carrot, cabbage, beet and onion vegetable mixtures," International Journal of Food Microbiology, vol. 64, no. 3, pp. 261-275, 2001.

[9] P. Teixeira, H. Castro, and R. Kirby, "Spray drying as a method for preparing concentrated cultures of Lactobacillus bulgaricus," Journal of Applied Bacteriology, vol. 70, no. 4, pp. 456-462, 1995.

[10] R. Di Cagno, G. Cardinali, G. Minervini et al., "Taxonomic structure of the yeasts and lactic acid bacteria microbiota of pineapple (Ananas comosus L. Merr.) and use of autochthonous starters for minimally processing," Food Microbiology, vol. 27, no. 3, pp. 381-389, 2010.

[11] M. R. Adams and C. J. Hall, "Growth inhibition of foodborne pathogens by lactic and acetic acids and their mixtures," International Journal of Food Science \& Technology, vol. 23, pp. 287-292, 1988.

[12] C. S. Andrés, L. Giannuzzi, and N. E. Zaritzky, "The effect of temperature on microbial growth in apple cubes packed in film and preserved by use of orange juice," International Journal of Food Science \& Technology, vol. 39, pp. 927-933, 2004.

[13] J. Koh, Y. Kim, and J. Oh, "Chemical characterization of tomato juice fermented with bifidobacteria," Journal of Food Science, vol. 75, no. 5, pp. C428-C432, 2010.

[14] H. Vega-Mercado, O. Martin-Belloso, B. L. Qin et al., "Nonthermal food preservation: Pulsed electric fields," Trends in Food Science \& Technology, vol. 8, pp. 151-157, 1997.

[15] R. F. McFeeters, "Fermentation microorganisms and flavor changes in fermented foods," Journal of Food Science, vol. 69, no. 1, pp. FMS35-FMS37, 2004.

[16] A. L. Servin, "Antagonistic activities of lactobacilli and bifidobacteria against microbial pathogens," FEMS Microbiology Reviews, vol. 28, no. 4, pp. 405-440, 2004.

[17] E. A. Szabo, L. Simons, M. J. Coventry, and M. B. Cole, "Assessment of control measures to achieve a food safety objective of less than $100 \mathrm{CFU}$ of Listeria monocytogenes per gram at the point of consumption for fresh precut iceberg lettuce," Journal of Food Protection, vol. 66, no. 2, pp. 256-264, 2003.

[18] J. Karovicova and Z. Kohajdova, "Lactic acid fermented vegetable juices," Horticultural Science - Prague, vol. 30, pp. 152-158, 2003.

[19] J. McLauchlin, M. Hampton, S. Shah, E. Threlfall, A. Wieneke, and G. Curtis, "Subtyping of Listeria monocytogenes on the basis of plasmid profiles and arsenic and cadmium susceptibility," Journal of Applied Microbiology, vol. 83, no. 3, pp. 381-388, 1997.

[20] S. B. Hunter, P. Vauterin, M. A. Lambert-Fair et al., "Establishment of a universal size standard strain for use with the pulsenet standardized pulsed-field gel electrophoresis protocols: Converting the national databases to the new size standard," Journal of Clinical Microbiology, vol. 43, no. 3, pp. 1045-1050, 2005.

[21] M. Perez and F. Saguir, "Transfer and subsequent growth and metabolism of Lactobacillus plantarum in orange juice medium during storage at 4 and 30॰C," Letters in Applied Microbiology, vol. 54, no. 5, pp. 398-403, 2012.

[22] A. C. Stratakos, G. Delgado-Pando, M. Linton, M. F. Patterson, and A. Koidis, "Industrial scale microwave processing of tomato juice using a novel continuous microwave system," Food Chemistry, vol. 190, pp. 1-24, 2016.

[23] I. D. S. Ferrari, J. V. de Souza, C. L. Ramos, M. M. da Costa, R. F. Schwan, and F. S. Dias, "Selection of autochthonous lactic acid bacteria from goat dairies and their addition to evaluate the inhibition of Salmonella typhi in artisanal cheese," Food Microbiology, vol. 60, pp. 1-35, 2016.

[24] J. Barbosa, S. Borges, and P. Teixeira, "Effect of different conditions of growth and storage on the cell counts of two lactic acid bacteria after spray drying in orange juice," Beverages, vol. 8, pp. 2-12, 2016.

[25] J. Barbosa, S. Borges, M. Amorim et al., "Comparison of spray drying, freeze drying and convective hot air drying for the production of a probiotic orange powder," Journal of Functional Foods, vol. 17, pp. 340-351, 2015.

[26] Z. E. Mousavi, S. M. Mousavi, S. H. Razavi, Z. Emam-Djomeh, and H. Kiani, "Fermentation of pomegranate juice by probiotic lactic acid bacteria," World Journal of Microbiology and Biotechnology, vol. 27, no. 1, pp. 123-128, 2011.

[27] A. L. F. Pereira, T. C. Maciel, and S. Rodrigues, "Probiotic beverage from cashew apple juice fermented with Lactobacillus casei," Food Research International, vol. 44, no. 5, pp. 1276-1283, 2011.

[28] B. Marchesini, A. Bruttin, N. Romailler, R. S. Moreton, C. Stucchi, and T. Sozzi, "Microbiological events during commercial meat fermentations," Journal of Applied Bacteriology, vol. 73, no. 3, pp. 203-209, 1992.

[29] L. O. Sunesen and L. H. Stahnke, "Mould starter cultures for dry sausages-selection, application and effects," Meat Science, vol. 65, no. 3, pp. 935-948, 2003.

[30] I. Essid and M. Hassouna, "Effect of inoculation of selected Staphylococcus xylosus and Lactobacillus plantarum strains on biochemical, microbiological and textural characteristics of a Tunisian dry fermented sausage," Food Control, vol. 32, no. 2, pp. 707-714, 2013.

[31] S. Crowley, J. Mahony, and D. Van Sinderen, "Comparative analysis of two antifungal Lactobacillus plantarum isolates and their application as bioprotectants in refrigerated foods," Journal of Applied Microbiology, vol. 113, no. 6, pp. 1417-1427, 2012.

[32] W. Lan, Y. Chen, H. Wu, and F. Yanagida, "Bio-protective potential of lactic acid bacteria isolated from fermented wax gourd," Folia Microbiologica, vol. 57, no. 2, pp. 99-105, 2012.

[33] V. F. Alves, R. C. R. Martinez, M. A. S. Lavrador, and E. C. P. De Martinis, "Antilisterial activity of lactic acid bacteria inoculated on cooked ham," Meat Science, vol. 74, no. 4, pp. 623-627, 2006.

[34] H. Albano, M. Oliveira, R. Aroso, N. Cubero, T. Hogg, and P. Teixeira, "Antilisterial activity of lactic acid bacteria isolated from "Alheiras" (traditional Portuguese fermented sausages): In situ assays," Meat Science, vol. 76, no. 4, pp. 796-800, 2007.

[35] D. Li, K. Ni, H. Pang, Y. Wang, Y. Cai, and Q. Jin, "Identification and antimicrobial activity detection of lactic acid bacteria isolated from corn stover silage," Asian-Australasian Journal of Animal Sciences, vol. 28, no. 5, pp. 620-631, 2015.

[36] M. R. Fazeli, N. Amirmozafari, R. G. nejad, and H. Jamalifar, "Antagonistic Action of Watermelon Juice Probioticated Using Different Strains of Lactobacilli against Salmonella typhimurium," Iranian Journal of Public Health, vol. 36, pp. 7073, 2007.

[37] A. Brillet, M.-F. Pilet, H. Prevost, M. Cardinal, and F. Leroi, "Effect of inoculation of Carnobacterium divergens V41, a 
biopreservative strain against Listeria monocytogenes risk, on the microbiological, chemical and sensory quality of coldsmoked salmon," International Journal of Food Microbiology, vol. 104, no. 3, pp. 309-324, 2005.

[38] B. B. Budde, T. Hornbæk, T. Jacobsen, V. Barkholt, and A. G. Koch, "Leuconostoc carnosum 4010 has the potential for use as a protective culture for vacuum-packed meats: Culture isolation, bacteriocin identification, and meat application experiments," International Journal of Food Microbiology, vol. 83, no. 2, pp. 171-184, 2003.

[39] R. Georgieva, P. Koleva, D. Nikolova, D. Yankov, and S. Danova, "Growth parameters of probiotic strain lactobacillus plantarum, isolated from traditional white cheese," Biotechnology \& Biotechnological Equipment, vol. 23, pp. 861-865, 2009.

[40] Y. Hernández, M. G. Lobo, and M. González, "Factors affecting sample extraction in the liquid chromatographic determination of organic acids in papaya and pineapple," Food Chemistry, vol. 114, no. 2, pp. 734-741, 2009.

[41] H. Rüssmann, H. Shams, F. Poblete, Y. Fu, J. E. Galán, and R. O. Donis, "Delivery of epitopes by the Salmonella type III secretion system for vaccine development," Science, vol. 281, no. 5376, pp. 565-568, 1998.

[42] B. T. Lucena, B. M. dos Santos, J. L. Moreira et al., "Diversity of lactic acid bacteria of the bioethanol process," BMC Microbiology, vol. 298, pp. 1-10, 2010.

[43] K. Y. Yoon, E. E. Woodams, and Y. Hang, "Probiotication of tomato juice by lactic acid bacteria," Journal of Microbiology, vol. 42, pp. 315-318, 2004.

[44] L. V. Reddy, J. Min, and Y. Wee, "Production of probiotic mango juice by fermentation of lactic acid bacteria," Microbiology and Biotechnology Letters, vol. 43, no. 2, pp. 120-125, 2015.

[45] Z. Kohajdova and J. Karovicova, "Sensory and chemical evaluation of lactic acid-fermented cabbage-onion juices," Chemical Papers, vol. 59, pp. 55-61, 2005.

[46] A. Casaburi, M.-C. Aristoy, S. Cavella et al., "Biochemical and sensory characteristics of traditional fermented sausages of Vallo di Diano (Southern Italy) as affected by the use of starter cultures," Meat Science, vol. 76, no. 2, pp. 295-307, 2007.

[47] L. A. Shelef, "Antimicrobial effects of lactates: a review," Journal of Food Protection, vol. 57, no. 5, pp. 445-450, 1994.

[48] D. Jankuloski, P. Sekulovski, L. Angelovski et al., "“"Effect of acetic, citric and lactic acid on Salmonella enteridis and Listeria monocytogenes," Journal of Hygienic Engineering and Design, pp. 93-96, 2012.

[49] W. A. Gould, "Quality evaluation of processed tomato juice," Journal of Agricultural and Food Chemistry, vol. 26, no. 5, pp. 1006-1011, 1978. 


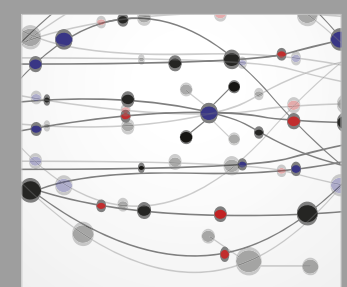

The Scientific World Journal
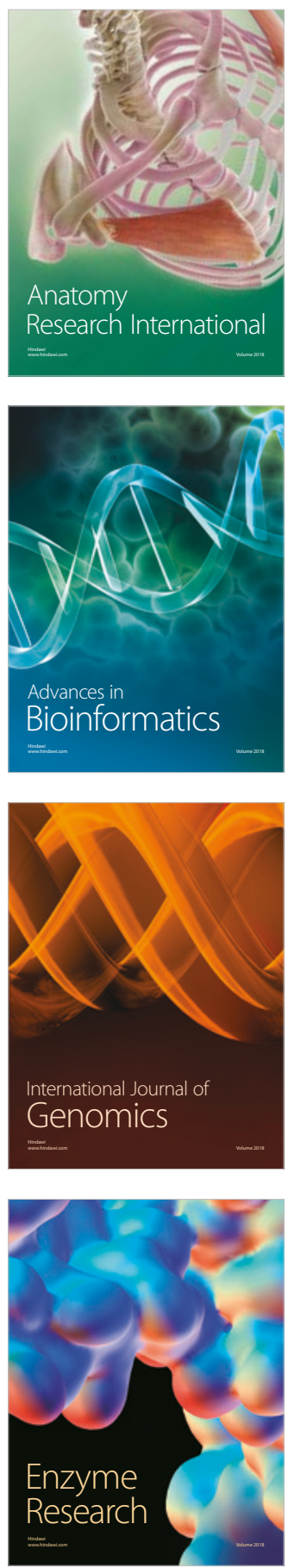
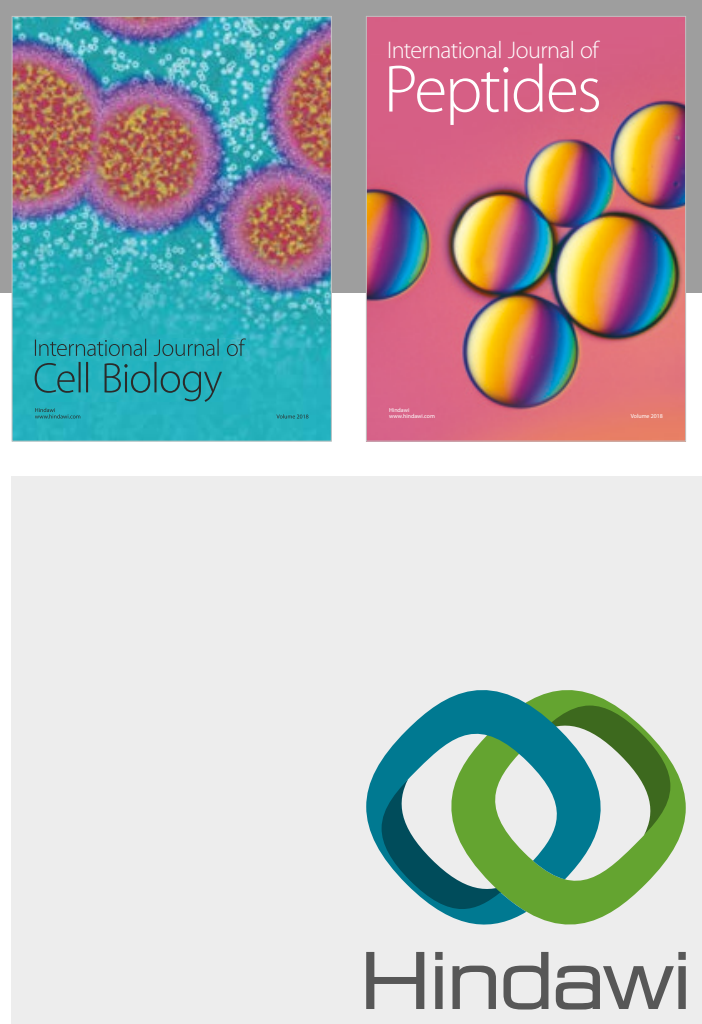

Submit your manuscripts at

www.hindawi.com
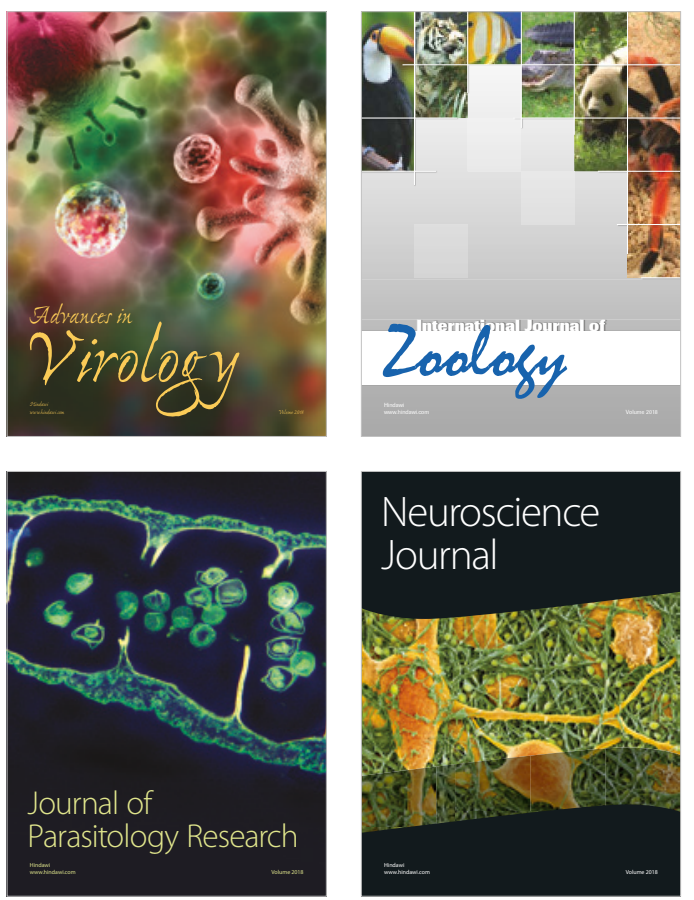
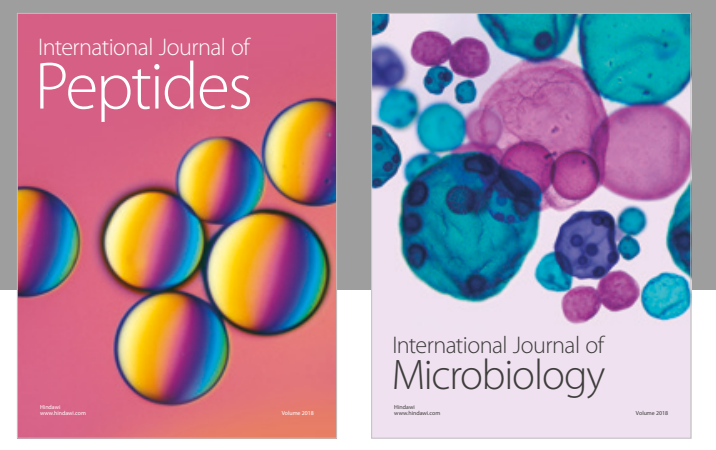

nternational Journal of Microbiology
Journal of
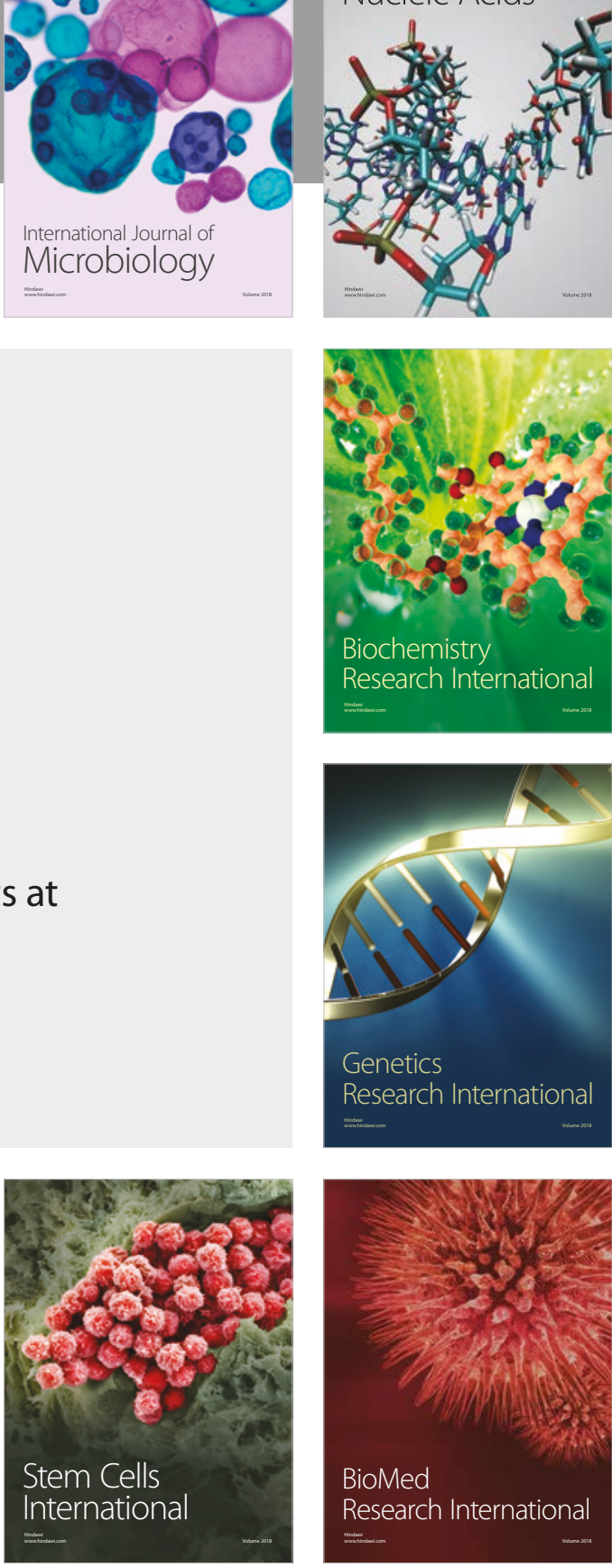
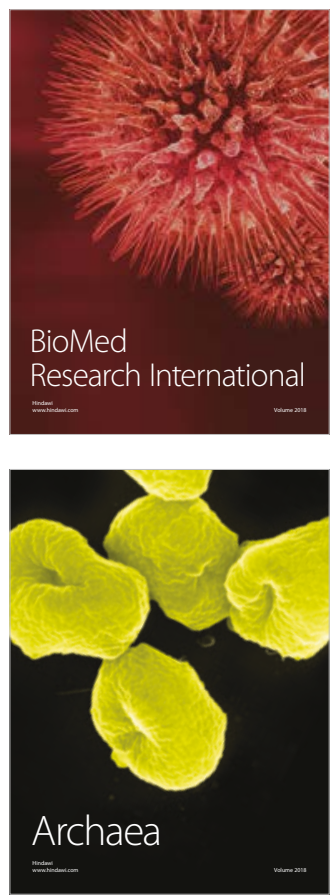